Karakış, Ö. (2021). The relationship between teaching profession perception and professional anxiety levels of prospective teachers. Bolu Abant İzzet Baysal Üniversitesi Eğitim Fakültesi Dergisi, $21(3), \quad 769-787$. https://dx.doi.org/10.17240/aibuefd.2021.21.64908-909065

Makalenin Türü / Article Type

Geliş Tarihi / Date Received

Kabul Tarihi / Date Accepted

Yayın Tarihi / Date Published
: Araștırma Makalesi / Researh Article

:03.04.2021

$: 10.06 .2021$

: 15.09 .2021

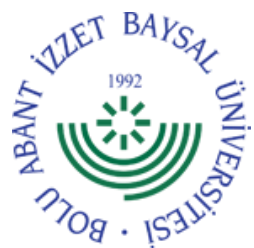

\title{
THE RELATIONSHIP BETWEEN TEACHING PROFESSION PERCEPTION AND PROFESSIONAL ANXIETY LEVELS OF PROSPECTIVE TEACHERS
}

\author{
Özlem KARAKIŞ ${ }^{1}$
}

\begin{abstract}
The aim of this study is to examine the relationship between teaching profession perception and professional anxiety levels of prospective teachers. A total of 387 prospective teachers, participating pedagogical formation certificate program, voluntarily participated in the study where descriptive and relational survey models were used. According to the results of the study, the prospective teachers within the scope of the study have moderate levels of professional anxiety and perception, the average scores in the teaching profession perception scale were significant in favour of the female prospective teachers, prospective teachers who participated in the program to do the teaching profession afterwards, who preferred a teaching department in university entrance exams priorly and who will take the Public Personnel Selection Exam (PPSE). The average scores in the professional anxiety scale were found to be significant in favour of male prospective and employed prospective teachers. In addition, it was determined that there was a low, positive, and meaningful relationship between prospective teachers' teaching profession perception and professional anxiety levels. Based on the findings of the present study, experimental studies to decrease their professional anxiety levels and increase their level of professional perceptions of prospective teachers are recommended for further research.
\end{abstract}

Key Words: Teaching profession, teaching profession perception, professional anxiety, pedagogical formation, teacher education

\section{PEDAGOJIK FORMASYON EĞITIMI ALAN ÖĞRETMEN ADAYLARININ ÖĞRETMENLIKK MESLEĞİNE YÖNELIKK ALGI VE MESLEKİ KAYGI DÜZEYLERİ ARASINDAKİ ILIŞKİ}

\section{ÖZ}

Bu araştırmanın amacı pedagojik formasyon eğitimi alan öğretmen adaylarının öğretmenlik mesleğine yönelik algı ve mesleki kaygı düzeyleri arasındaki ilişkiyi incelemektir. Betimsel ve ilişkisel tarama modellinin kullanıldığı araştırmaya, pedagojik formasyon sertifika programında yer alan 387 öğretmen adayı gönüllü olarak katılmıştır. Araştırmanın verilerine göre, araştırma kapsamındaki öğretmen adaylarının orta düzeyde mesleki kaygı ve algı düzeylerine sahip oldukları; öğretmenlik mesleğine yönelik algı ölçeğindeki ortalama puanların kadın, programa öğretmenlik yapmak amacıyla katılan, üniversite giriş sınavlarında öğretmenlik bölümünü tercih etmiş olan ve Kamu Personeli Seçme Sınavı'na (KPSS) girecek olan öğretmen adaylarının lehine anlamlı olduğu belirlenmiştir. Mesleki kaygı ölçeğindeki ortalama puanların, erkek ve çalışan öğretmen adaylarının lehine anlamlı olduğu belirlenmiştir. Araştırmada ayrıca, öğretmen adaylarının öğretmenlik mesleğine yönelik algı ve mesleki kaygı arasında düşük düzeyde, pozitif ve anlamlı bir ilişki olduğu belirlenmiştir. $\mathrm{Bu}$ araştırmanın bulgularına dayanarak, öğretmen adaylarının mesleki kaygı düzeylerini azaltmaya ve mesleki algı düzeylerini artırmaya yönelik deneysel çalışmalar yapılması önerilmektedir.

Anahtar Kelimeler: Öğretmen adayı, öğretmenlik mesleğine yönelik algı, mesleki kaygı, pedagojik formasyon, öğretmen eğitimi

\footnotetext{
I Bolu Abant İzzet Baysal Üniversitesi, Yabancı Diller Yüksekokulu, karakis_o@ibu.edu.tr, 으 https://orcid.org/0000-0001-8934-3912
} 


\section{INTRODUCTION}

Educational institutions' ability to perform the tasks of raising people who can use information and technology, create, learn, solve problems, think critically and creatively depends on the qualifications of educational services, students, and teachers. As teachers constantly interact with others (Özoğlu, 2011, p. 143), their personality and psychological traits, attitudes, and interests are even more important than teaching methods and awareness in pedagogical instruction (Chotas \& Thoresen, 1976, pp. 159-184; Memişoğlu, 2006). In other words, personal and psychological traits being thrown back during the education process are at least as effective as the professional competencies for the success of teachers (Demirel, 2003; Yazıc1, 2009). In order for the teachers to educate individuals and increase the quality of education in accordance with the requirements of the age, their attitudes towards the profession should be positive-constructive, and affective domain competencies and positive psychological characteristics are required. In this context, it can be said that prospective teachers' perceptions towards the profession and anxiety levels about that profession are important psychological variables affecting their professional success.

\subsection{Perception towards teaching profession}

The professional perception of an individual is effective on factors such as having self-confidence about their profession in cognitive, affective, and behavioural sense, being conscious of what they want, being successful and peaceful in professional life, affecting the society and individuals in which they live in a positive way and improving their professional skills (Akyüz, 1978; Luthans, 1995). Today, not only aptitude, interests, and values, but also the financial return of the profession, status, suitability for the present age, and the idea of self-assurance and self-independence are effective on the perception of that profession (Kuzgun, 2000; Özyürek \& Kılıç Atıcı, 2002). Prospective teachers' professional competencies and perceptions are also vital to their success in their profession. Teachers create their own professional ideas and perceptions through their experiences during their pupillage and professional life (Can, 1987, p. 160), and can be more effective in this profession, thanks to the positive professional perception (Erdem et al., 2005). In order to increase own academic success and become a qualified teacher in the future, prospective teachers should develop positive thinking (Semerci, 2001), attitude and perception about the teaching profession (Terzi \& Tezci, 2007). Simply stated, prospective teachers need to have a positive professional perception to be open to improvement, acquire current professional skills, and create a successful teacher profile.

In the literature on the perception of the teaching profession, there are studies in which it has been found that prospective teachers perceive the teaching profession as life, guide, devotion, quality, disappointment, and manager (Çocuk et al., 2015) and parent, family, guide, shepherd, gardener, light etc. (Yllmaz et al., 2013). At the graduation stage, that the reasons of prospective teachers for choosing this profession are intrinsic, self-seeking, altruistic $(24.11 \%)$ and extrinsic reasons, and that $15(21 \%)$ out of 71 female prospective teachers and $48(56 \%)$ out of 86 males would not choose the profession again are also determined (Çermik et al., 2010). In the study conducted by Nenty et al. (2015), it was determined that professional perceptions were higher in male prospective teachers and their perception of the profession had a significant effect on the motivation to be successful in teacher training programs, attitude towards teacher training programs, the value they give to the program, and the perceptions of effectiveness of the program. Also in the literature, that the reasons for prospective teachers' choice of the profession are, respectively, their own will, job security and teacher influence (Erdemir, 2010); their perceptions about the teaching profession changed with school experience (Tarman, 2012); most of them could not find their expectations about the profession, thought their professions were not respected and were worried about the future (Karamustafaoğlu \& Özmen, 2004) were determined. In their study, Erus and Zeren (2017) found that prospective teachers attended this program because they liked teaching, might need this document in the future, and thought that the working conditions of teaching profession were good; consider the teaching profession to be respected and that almost all of them planned to teach in the future. It is also among the data obtained from the studies that $49.7 \%$ of them preferred the teaching profession mostly for moral reasons and then for financial reasons and that $49.7 \%$ perceived the teaching profession as a trainer and guide (Kart, 2016) and most of the prospective teachers consider the teaching profession as respectable and all of them want to do this profession (Gülşen \& Gündüz, 2016). That the prospective teachers thought that pedagogical formation certificate program would make it easier to become a teacher, learned a lot of professional knowledge from this program and thought it would be more efficient if the program were long (Kiraz \& Dursun, 2015) and thought that the teaching profession requires responsibility and sacrifice (Özdemir \& Erol, 2015) were also determined in the studies of the related literature. Owen-Korkut et al. (2012) found that the reasons of prospective teachers for choosing the teaching profession were individual and systemic factors such as interest in the profession, the score obtained in the university entrance exam to be sufficient for this department, the suitability for the personality of the field, and the high possibility of finding a job. In the literature, there are also studies in which only $5.6 \%$ of the prospective teachers thought that the pedagogical formation certificate program would meet the teaching profession competencies and that the program was an obstacle to squeeze the program into a short time (Yalçın İncik \& Akay, 
2015); approximately $40 \%$ of them unwillingly chose their field of study, $87 \%$ wanted to teach, and $81 \%$ had negative thoughts about their professional future (Şahin, 2011). In the literature, that only $55.62 \%$ of prospective teachers chose the teaching profession because they liked the teaching profession, $75.62 \%$ had anxiety of finding a job in the future, $48.75 \%$ wanted to change their fields when they had an opportunity (Taş, 2010); there was a negative relationship between professional perceptions and hopelessness levels (Dinçer et al., 2015) were also determined. Tataroğlu et al. (2011) found that the majority of them chose this profession because they were interested and loved and found teaching professsion suitable for them. The factors that affect the selection of this profession were, respectively, suitability to their personality, sufficient placement score, and their ideal profession (Y1lmaz \& Doğan, 2015). In their study, Chong and Low (2009) determined that prospective teachers' professional perceptions, which were high at the beginning of the school experience, decreased at the end of this experience. According to the data gained from the studies conducted in the literatüre, we can understand that prospective teachers have both positive and negative attitudes and thoughts about the profession, they think that it is a respected but financially unsatisfactory profession, they like the certificate program but wish that it would be longer, a few of them would rather choose a different profession, and some of them have professional anxiety as well.

\subsection{Professional anxiety towards teaching profession}

Initially, during their pupillage and professional life, prospective teachers have some anxiety related to the teaching profession requiring expertise (Fuller, 1969, p. 207) because of a new lifestyle, new duties, and responsibilities (Uluğ et al., 2014). Cabı and Yalçınalp (2009) determined that prospective teachers have anxiety about communication with students, finding a job, school and economic life, professional adoption, and environment. Fuller (1969, p. 211) gathered the prospective teachers' anxiety about the profession under three groups as student, duty, and self-centred anxieties. The prospective teachers, who are worried about continuing their teaching profession successfully and are constantly under heavy stress because of this, have self-centred; the ones who are concerned about being a good teacher and researching contemporary teaching methods and materials in their field have task-centred and the ones who desire to meet the social, mental, and emotional needs of all of their students in the best way also have student-centred anxiety. Fuller and Parsons (1974) identified task and self-centred anxiety as immature stage, while student-centred anxiety as the most mature stage. It is also established in the literature that professional anxiety occurs simultaneously but not in a developmental order (Marso \& Pigge, 1998; Reeves \& Kazelskis, 1985). Fuller (1969) evaluated prospective teachers' professional anxiety from a developmental perspective and suggested that the prospective teachers themselves should experience and overcome it to be a better teacher. Professional anxiety among prospective teachers is expected to be at the lowest level during their first classroom experience, as they are not fully confronted with the fact that they are teaching, increasing in the years that follow, mature and decreasing through years of experience (Fuller et al., 1974). Teachers who are committed to raising future generations will be able to have confidence in themselves by starting their professional life free from their professional anxiety (Taşğın, 2006).

When the literature on professional anxiety of prospective teachers was examined, it was found that the professional anxiety of teacher candidates did not differ according to their gender (Abalı Öztürk et al., 2019; Atmaca, 2013; Bozdam \& Taşkın, 2011; Dilmaç, 2010; Dinçer et al., 2015; Dursun \& Karagün, 2012; Kafkas et al., 2010; Karademir \& Tezel, 2011; Keskin, 2017; Ünald1 \& Alaz, 2008); they had a low level of professional anxiety (Dilmaç, 2010; Doğan \& Çoban, 2009; Kalemoğlu Varol et al., 2014; Köse, 2006) and moderate occupational anxiety (Bozdam \& Taşkın, 2011; Keskin, 2017; Serin et al., 2015; Tabancalı et al., 2016); they had a high level of professional anxiety (Akgün \& Özgür, 2014; Donmuş et al., 2007; Sezgin Nartgün \& Gökçer, 2014); in all types of anxiety, the average of female teacher candidates was higher than that of men (Çakmak \& Hevedanl1, 2005; Çubukçu \& Dönmez, 2011; Kaya \& Büyükkasap, 2005; Marso \& Pigge, 1998; Tümerdem, 2007; Türkdoğan, 2014; Ünaldı \& Alaz, 2008); that men's occupational anxiety was higher than women's (Akgün \& Özgür, 2014; Donmuş et al., 2007); they had the idea that they would experience anxiety mostly in classroom management and least in communication with their colleagues (Çakmak, 2008); their anxiety levels decreased as their age increased (Bozdam \& Taşkın, 2011); the age factor did not significantly affect anxiety levels statistically (Atmaca, 2013); professional concerns did not show any significant differentiation according to the type of high school they graduated from (Türkdoğan, 2014); professional anxiety levels did not differ significantly according to parental education level (Türkdoğan, 2014); as their grade levels increased, their occupational anxiety levels increased (Boz, 2008; Çubukçu \& Dönmez, 2011; Gözler et al., 2017; Gümrükçü Bilgici \& Deniz, 2016; Özday1, 2000) or they did not change (Akgün \& Özgür, 2014); there was a significant relationship between professional anxiety and academic self-efficacy (Donmuş et al., 2007); professional anxiety levels did not differ depending on whether there was a teacher in the family (Akgün \& Özgür, 2014); there was no significant difference between the variables of occupational anxiety and working hours and conditions of the profession, liking the profession and choosing it for job guarantee reasons (Akgün \& Özgür, 2014); the self-centered anxiety scores of the younger teacher candidates were significantly higher than the other pre-service teachers, but this difference was not detected in task and student-centered anxiety types (Dursun \& Karagün, 2012); success orientation was an important 
predictor of professional anxiety (Gözler et al., 2017); women had higher appointing concerns and men had higher task-centered concerns (Gümrükçü Bilgici \& Deniz, 2016); the higher the self-efficacy scores were, the lower the professional anxiety scores were (Kafkas et al., 2010); there was no significant difference in terms of professional anxiety levels regarding whether they wanted the department they studied or not (Kafkas et al., 2010); there was a significant relationship between occupational anxiety and attitude towards the profession (Kalemoğlu Varol et al., 2014; Serin et al., 2015) and there wasn't (Akgün \& Özgür, 2014); there was a negative relationship between attitude and anxiety, and those who thought negatively about finding a job were more anxious (Doğan \& Çoban, 2009); women experienced more anxiety in task-centered and student-centered anxiety (Tabancal1 et al., 2016); there were no significant differences according to the variables of the department, class level, parental education level and the individual who performed the teaching profession in the family; occupational anxiety levels of those who preferred the teaching profession at higher ranks were lower (Abalı Öztürk et al., 2019); they thought they would have the most anxiety of not finding a job after graduation (Kaya \& Büyükkasap, 2005); prospective teachers with higher academic skills decreased more than their less talented peers (Marso \& Pigge, 1998) and their anxiety levels decreased at the end of the teaching practice lesson (Pigge \& Marso, 1987, 1990). To sum up, prospective teachers have different levels of professional anxiety; their anxiety levels both differ and don't differ according to their age and gender; the higher the self-efficacy scores are the lower the professional anxiety scores; there is both a positive and negative relationship between professional anxiety and attitude towards the profession and there are both significant and insignificant differences according to the variables of the department, class level, parental education level.

Considering that the future professional performance of prospective teachers will be influenced by their personal and psychological characteristics and perceptions of the teaching profession, evaluating teaching profession perception and professional anxiety levels of the prospective teachers included in this program is of great value. As can be understood from the related studies, both professional perception and anxiety that prospective teachers experience are affected from many factors such as attitude, intrinsic and extrinsic motivation et al.; therefore, it is thought that examining the interactions of these two important factors, perception, and anxiety of prospective teachers, with each other will also contribute much to the literature. Furthermore, it is considered that this study examining the different dimensions of pedagogical formation certificate programs will also help monitor and update those programmes through a more pedagogical perspective.

\subsection{Purpose of the research}

The aim of this study is to examine the relationship between the teaching profession perception and professional anxiety levels of prospective teachers having pedagogical formation education. In order to determine this relationship, the following questions were answered:

1- What are the teaching profession perceptions and professional anxiety levels of prospective teachers taking pedagogical formation education?

2- Is there a relationship between prospective teachers' teaching profession perception and their professional anxiety levels?

3- Do prospective teachers taking pedagogical formation education vary in their perception of the teaching profession and professional anxiety levels according to their gender, age, educational status, reason for taking pedagogical formation certificate program, preference of entering the teaching department priorly in the university entrance exam and desire to take the PPSE?

\section{METHOD}

\subsection{Research model}

This research was structured in a descriptive survey model as it primarily aims to reveal the teaching profession perception and professional anxiety levels of prospective teachers. Studies aiming to identify an existing situation shall be examined within the scope of the descriptive survey model (Balc1, 2005; Gay \& Airasian, 2000; Karasar, 1995). As the relationship between teaching profession perception and professional anxiety levels of prospective teachers is also examined in the present study, it is also structured with a relational survey model. According to Karasar (2013), relational survey aims to determine the presence and / or degree of interchange between two and more variables.

\subsection{Study group}

The study was carried out by random sampling method on 387 volunteer prospective teachers, out of 750 prospective teachers, studying at pedagogical formation certificate program at education faculty of a large-scale university located in Turkey's Western Black Sea Region. Frequency and percentage values of the independent variables are summarized in Table 1. 
Table 1.

Frequency and Percentage of Independent Variables

\begin{tabular}{llll}
\hline Variable & Level & $\mathbf{N}$ & $\mathbf{\%}$ \\
\hline \multirow{2}{*}{ Gender } & Female & 274 & 70,80 \\
Age & Male & 113 & 29,20 \\
\hline \multirow{2}{*}{ Educational Status } & $20-30$ & 340 & 87,90 \\
& 31 and above & 46 & 11,90 \\
\multirow{2}{*}{ Working Status } & High school graduate & 283 & 73,10 \\
& Graduate & 103 & 26,60 \\
\hline \multirow{2}{*}{ Reason for joining the program } & Employed & 66 & 17,10 \\
& Unemployed & 321 & 82,90 \\
\hline \multirow{2}{*}{ Preference of teaching department } & To do teaching profession & 315 & 81,40 \\
& Just to get the certificate & 71 & 18,30 \\
\hline \multirow{2}{*}{ PPSE entering status } & Yes & 172 & 44,40 \\
& No & 203 & 52,50 \\
\hline
\end{tabular}

Of 387 prospective teachers, 274 of them are female and 113 of them are male. There are 340 prospective teachers in the 20-30 age range and 46 prospective teachers in the age range of 31 and above. 283 prospective teachers are undergraduate students and 103 of them are graduates. While 66 prospective teachers are currently working, 321 of them are not. While the number of prospective teachers stating their reason for joining the pedagogical formation certificate program as "perform teaching profession" is 315 , the number of prospective teachers whose reason is "just to get the certificate" is 71.172 prospective teachers preferred teaching department priorly at the university entrance examination, of which 203 did not. The number of prospective teachers stating that they will take PPSE is 325 , while 62 of them are reluctant.

\subsection{Data collection tools}

In the study, "Personal Information Form" prepared by the researcher was used to obtain the personal information of the prospective teachers. The Professional Anxiety Scale for Prospective Teachers and The Perception of Teaching Profession Scale were also used in the study.

\subsubsection{Professional Anxiety Scale for Prospective Teachers}

Professional Anxiety Scale for Prospective Teachers developed by Cabı and Yalçınalp (2013) was used to determine the levels of professional anxiety levels of prospective teachers. The scale consists of total 45 items that are graded as 5-point Likert type in "strongly disagree" - "strongly agree" range and eight factors (Task Centred Anxiety, Economic / Social Centred Anxiety, Student / Communication Centred Anxiety, Colleague and Parent Centred Anxiety, Personal Development Centred Anxiety, Appointment Centred Anxiety, Compliance Centred Anxiety, School Management Centred Anxiety), and its corrected item-total score correlations of the factors range from 0.23 to 0.73 , and Cronbach's alpha coefficients ranged between 0.94 to 0.67 . The Cronbach's alpha internal consistency coefficient of the scale was found to be 0.95 .

\subsubsection{Perception of Teaching Profession Scale}

In order to determine the professional teaching perception levels of the students, "Perception of Teaching Profession Scale" developed by Öztürk et al. (2005) was used. Items are graded as 5-point Likert type in "strongly disagree" - "strongly agree" range. Cronbach's alpha coefficients of the factors, namely Teaching Skill, Career Choice and Glorifying Teaching, range as $0.64,0.80$ and 0.67 , respectively. The Cronbach's alpha internal consistency coefficient of the scale was found to be 0.78 .

As both scales were suitable for total scoring, the number of factors and the number of prospective teachers' demographic characteristics were high, the present study was analysed on the total scores of the scales. In the present study, the normality of the general total and factor scores of the scales were evaluated by examining the kurtosis and skewness coefficients and the results are summarized in Table 2.

\section{Table 2.}

Descriptive Analysis Results of Scale and Factors

\begin{tabular}{lccccccc}
\hline Scale & N & Minimum & Maximum & Average & S.D. & Skewness & Kurtosis \\
\hline Anxiety & 387 & 45 & 225 & 158.59 & 39.41 & -0.64 & -0.10 \\
Perception & 387 & 41 & 100 & 77.57 & 11.45 & -0.33 & -0.42 \\
\hline S.D: Standard deviation & & & & & & &
\end{tabular}


As a result of kurtosis and skewness coefficients, it was observed that these coefficients remained between \pm 1.5 . According to Pituch and Stevens (2016, p. 228), if the kurtosis and skewness coefficients are within the \pm 1.5 limit, the distribution of the data set is normally distributed.

As a result of the confirmatory factor analyses (CFA) performed in Mplus program to test the structural validity of scales, related goodness of fit results of the scales are summarized in Table 3.

\section{Table 3.}

Goodness of Fit Index for Factor Structure of the Scales

\begin{tabular}{llll}
\hline Goodness of Fit Index & Acceptable Limit & Anxiety Scale & Perception Scale \\
\hline $\mathbf{X}^{2} / \mathbf{s d}$ & $<5$ Medium level & $3066.58907=3.34$ & $1218.04 / 167=7.29$ \\
CFI & $>0.90$ & 0.96 & 0.89 \\
NNFI & $>0.90$ & 0.95 & 0.88 \\
RMSEA & $<0.08$ & 0.07 & 0.12 \\
\hline
\end{tabular}

(Çokluk et al., 2010, pp. 271-272)

As a result of the CFA of the Professional Anxiety Scale for Prospective Teachers, consisting eight dimensions, the standardized path coefficients of the items varied between $0.525-0.943$, and it was observed that the correlations between the factors varied between $0.211-0.873$. Also, when the fit indexes given in Table 2.3 are examined, it is seen that the data fit well to the structure tested. The general reliability of the Professional Anxiety Scale for Prospective Teachers was calculated as 0.982 with stratified alpha. Cronbach et al. (1965) proposed the use of the Stratified Cronbach Alpha coefficient for the reliability of the total scores obtained from measurement instruments with factors. The stratified Cronbach's alpha coefficient was calculated using "sirt" (Robitzsch, 2017) package in $\mathrm{R}$ program. The scale is evaluated on both factor scores and total score. As a result of CFA, it was observed that the three-dimensional structured Perception Scale for Teaching Profession's standardized path coefficients ranged between 0.415 - 0.934 except for the first and third items, and it was statistically significant. The correlations between the factors were observed to vary between $0.268-0.666$. The overall reliability of the scale was calculated as 0.853 with layered alpha.

\subsection{Data analysis}

The results of the first research question are summarized with mean and standard deviation values. In the second research question, the relationship between the scale total scores was expressed by Pearson correlation coefficient as the data showed normal distribution. Since fully agreed intervals was not found in the interpretation of the correlation coefficient in terms of magnitude, the results of this study have been interpreted using the limits that Kirk (2008, p. 138) and Büyüköztürk (2011, p. 32) stated as they use frequently. These limits are very high if the absolute value of the correlation coefficient is $r \geq 0.90 ; r=0.70-0.89$ if high; if $r=0.69-0.30$, it is defined as a moderate relationship and $r \leq 0.29$ as a low-level relationship. The third research question was examined by t-test of parametric tests because of the normal distribution of data, sufficient observations in the categories of independent variables and two categories of independent variables. Levene test, being used to determine the homogeneity of the groups during T-test, was performed for all groups, and at the level of 0.05 Levene test results were not statistically significant, so the variance of the groups was found to be homogeneous. The statistical analysis performed based on the research questions were carried out on the total scores due to the high number of independent variables and factors.

\subsection{Ethical permission of the study}

In this study, all the rules specified to be followed within the scope of "Higher Education Institutions Scientific Research and Publication Ethics Directive" were complied with. None of the actions specified under the heading "Actions Contrary to Scientific Research and Publication Ethics", which is the second part of the directive, have been taken.

\section{Ethics committee permission information}

Name of the committee that made the ethical evaluation: Bolu Abant İzzet Baysal University Human Research Ethics Committee in Social Sciences

Date of ethical evaluation decision: 03.05.2019

Ethics assessment document issue number: 2019/187

\section{RESULTS}

This section contains the findings of each research question, respectively. 


\subsection{Findings on the first research question}

Teaching perception and professional anxiety levels of prospective teachers were examined with mean and standard deviation values of scale total scores and the calculated results are summarized in Table 4.

Table 4.

Results of Descriptive Analysis of the Scales

\begin{tabular}{lcc}
\hline Scales & Average & SD \\
\hline Perception & 77.57 & 11.45 \\
Anxiety & 158.59 & 36.41 \\
\hline
\end{tabular}

When Table 4 is examined, it is seen that the prospective teachers' teaching profession perceptions are at medium level with 77.57 and the professional anxiety scores of them are moderate level with an average of 158.59.

\subsection{Findings on the second research question}

The relationship between teaching profession perception and professional anxiety levels of prospective teachers was examined with Pearson correlation coefficient and summarized in Table 5.

\begin{tabular}{|c|c|c|}
\hline $\begin{array}{l}\text { Table } 5 . \\
\text { Pearson Cor }\end{array}$ & & \\
\hline Scales & Perception & Anxiety \\
\hline Perception & 1.00 & $0.15^{* *}$ \\
\hline Anxiety & $0.15 * *$ & 1.00 \\
\hline
\end{tabular}

When Table 5 is examined, it is seen that there is a low-level, positive, and significant relationship between teaching profession perception and professional anxiety scores $(r=0.15 ; p<0.01)$.

\subsection{Findings on the third research question}

Independent groups t-test was used to determine whether prospective teachers' teaching profession perception and professional anxiety levels change according to the independent variables.

a) Independent groups t-test results related to whether prospective teachers' teaching profession perception and professional anxiety levels change according to gender are given in Table 6.

Table 6.

t-test Results by Gender

\begin{tabular}{llcccccc}
\hline Scale & Variable & N & Average & S.D. & t & sd & p \\
\multirow{2}{*}{ Perception } & Female & 274 & 79.07 & 10.87 & \multirow{2}{*}{4.01} & 385 & \multirow{2}{*}{$0.00^{*}$} \\
& Male & 113 & 73.95 & 12.03 & & & \\
\hline \multirow{2}{*}{ Anxiety } & Female & 274 & 154.69 & 39.79 & -3.06 & \multirow{2}{*}{385} & \multirow{2}{*}{$0.02^{*}$} \\
\hline${ }^{* p<0,05}$ & Male & 113 & 168.04 & 36.97 & & &
\end{tabular}

When Table 6 is examined, it is seen that the average teaching profession perception scores of female and male prospective teachers are 79.07 and 73.95 , respectively, and the difference between the two means is statistically significant in favor of female prospective teachers $(t=4.01 ; \mathrm{p}=0.00)$. According to this result, it can be said that the perception scores of female prospective teachers are higher than the perception scores of males. In addition, mean scores of professional anxiety scale scores of female and male prospective teachers are 154.69 and 168.04, respectively, and the difference between these two averages is statistically significant in favor of males $(t=-3.06$ : $\mathrm{p}=0.02$ ).

b) Independent groups t-test results regarding whether teaching profession perception and professional anxiety levels of the prospective teachers change according to their age groups are given in Table 7.

Table 7.

t-test Results Regarding Age

\begin{tabular}{llcccccc}
\hline Scale & Variable & N & Average & S.D. & t & sd & p \\
\multirow{2}{*}{ Perception } & 20-30 years old & 340 & 77.37 & 11.57 & -0.83 & \multirow{2}{*}{384} & \multirow{2}{*}{0.41} \\
\hline \multirow{2}{*}{ Anxiety } & 31 and above & 46 & 78.87 & 10.59 & & \\
& 20-30 years old & 340 & 157.79 & 39.87 & \multirow{2}{*}{0.98} & \multirow{2}{*}{384} & \multirow{2}{*}{0.33} \\
\hline
\end{tabular}


When Table 7 is examined, it is seen that the average teaching profession perception scale scores of prospective teachers in the 20-30 age and 31 and older age groups are 77.37 and 78.87, respectively, and there is no significant difference between the mean scores of the two groups $(\mathrm{t}=-0.83, \mathrm{p}=0.41)$. Moreover, professional anxiety scale mean scores of prospective teachers between the ages of 20-30 and 31 and older are 157.79 and 163.89, respectively, and the difference between these two averages is not statistically significant $(\mathrm{t}=-0.98: \mathrm{p}=0) .33)$.

c) Independent groups t-test results related to whether teaching profession perception and professional anxiety levels of the prospective teachers change according to their educational status are given in Table 8 .

\section{Table 8.}

t-test Results According to Educational Status

\begin{tabular}{|c|c|c|c|c|c|c|c|}
\hline Scale & Variable & $\mathbf{N}$ & Average & S.D. & $\mathbf{t}$ & sd & $\mathbf{p}$ \\
\hline \multirow{2}{*}{ Perception } & Undergraduate & 283 & 77.74 & 11.74 & \multirow{2}{*}{-0.33} & \multirow{2}{*}{375} & \multirow{2}{*}{0.97} \\
\hline & Graduate & 94 & 77.79 & 10.43 & & & \\
\hline \multirow{2}{*}{ Anxiety } & Undergraduate & 283 & 156.87 & 39.68 & \multirow{2}{*}{-1.56} & \multirow{2}{*}{375} & \multirow{2}{*}{0.12} \\
\hline & Graduate & 94 & 164.19 & 38.64 & & & \\
\hline
\end{tabular}

When Table 8 is examined, it is seen that the average perception scores of the undergraduate and graduate prospective teachers are 77.74 and 77.79 , respectively, and there is no significant difference between mean scores of the two groups $(\mathrm{t}=-0.33 ; \mathrm{p}=0.97)$. On the professional anxiety scale, the mean scores of undergraduate and graduate prospective teachers are 156.87 and 164.19, respectively, and the difference between these two averages is not statistically significant $(\mathrm{t}=-1.56: \mathrm{p}=0.12)$.

d) Independent groups t-test results related to whether prospective teachers' teaching profession perception and professional anxiety levels change according to their employment status are given in Table 9.

Table 9.

t-test Results According to Employment Status

\begin{tabular}{|c|c|c|c|c|c|c|c|}
\hline Scale & Variable & $\mathbf{N}$ & Average & S.D. & $\mathbf{t}$ & sd & $\mathbf{p}$ \\
\hline \multirow{2}{*}{ Perception } & Employed & 66 & 76,61 & 11.47 & \multirow{2}{*}{-0.75} & \multirow{2}{*}{385} & \multirow{2}{*}{0.45} \\
\hline & Unemployed & 321 & 77,77 & 11,45 & & & \\
\hline \multirow{2}{*}{ Anxiety } & Employed & 66 & 169.29 & 36.89 & \multirow{2}{*}{2.44} & \multirow{2}{*}{385} & \multirow{2}{*}{$0.02 *$} \\
\hline & Unemployed & 321 & 156.39 & 39.61 & & & \\
\hline
\end{tabular}

*p<0.05

When Table 9 is examined, it is seen that the mean scores of employed and unemployed prospective teachers in teaching profession perception scale were 76.61 and 77.77 , respectively, and there is no significant difference between the average scores of the two variables $(\mathrm{t}=-0.75 ; \mathrm{p}=0,45)$. On the other hand, mean scores of professional anxiety scales of employed and unemployed prospective teachers are 169.29 and 156.39, respectively, and the difference between these two averages is statistically significant in favor of employed ones $(\mathrm{t}=2.44: \mathrm{p}=$ $0.02)$.

e) Independent groups t-test results related to whether prospective teachers' teaching profession perception and professional anxiety levels change according to their reasons of participating in the program are given in Table 10.

Table 10.

t-test Results According to the Reasons of Participation in the Program

\begin{tabular}{|c|c|c|c|c|c|c|c|}
\hline Scale & Variable & $\mathbf{N}$ & Average & S.D. & $\mathbf{t}$ & sd & $\mathbf{p}$ \\
\hline \multirow{2}{*}{ Perception } & To do the teaaching profession & 315 & 79.59 & 10.53 & \multirow{2}{*}{8.02} & \multirow{2}{*}{384} & \multirow{2}{*}{$0.00 *$} \\
\hline & Just to get the certificate & 71 & 68.42 & 10.92 & & & \\
\hline \multirow{2}{*}{ Anxiety } & To do the teaaching profession & 315 & 158.04 & 39.22 & \multirow{2}{*}{-0.67} & \multirow{2}{*}{384} & \multirow{2}{*}{0.50} \\
\hline & Just to get the certificate & 71 & 161.52 & 40.44 & & & \\
\hline
\end{tabular}

${ }^{*} p<0.05$

When Table 10 is analyzed, it is seen that the mean teaching professional perception scores of the prospective teachers who stated their reason for participating in pedagogical formation education as "do the teaching profession" and "just to get the certificate" are medium level as 79.59 and 68.42, respectively and the difference observed between the two means is statistically significant in favor of prospective teachers who stated their reason as to do the teaching profession $(\mathrm{t}=8,02) \cdot \mathrm{p}=0.00)$. On the other hand, it was seen that the mean professional anxiety scale scores of the prospective teachers of both groups are medium as 158.04 and 161.52, respectively and the difference between these two means is not statistically significant $(t=-0.67: p=0.50)$. 
f) Independent groups t-test results related to whether prospective teachers' teaching profession perception and professional anxiety levels change according to their preference of teaching department priorly in university entrance exams are given in Table 11.

\section{Table 11.}

t-test Results According to Preference of Teaching Department Priorly in University Entrance Exams

\begin{tabular}{llcccccc}
\hline Scale & Variable & N & Average & S.D. & t & sd & p \\
\hline \multirow{2}{*}{ Perception } & Yes & 172 & 79.99 & 10.56 & \multirow{2}{*}{3.80} & \multirow{2}{*}{373} & $0.00 *$ \\
& No & 203 & 75.57 & 11.80 & & \multirow{2}{*}{0.73} \\
\hline \multirow{2}{*}{ Anxiety } & Yes & 172 & 157.90 & 39.45 & \multirow{2}{*}{0.35} & \multirow{2}{*}{373} \\
& No & 203 & 159.33 & 39.76 & & & \\
\hline
\end{tabular}

$* \mathrm{p}<0.05$

When Table 11 is examined, it is seen that teaching profession perception scale mean scores of prospective teachers who preferred and who did not prefer a teaching department in university entrance exams priorly are 79.99 and 75.57, respectively, and the difference between the two means is statistically significant in favor of prospective teachers who preferred a teaching department in university entrance exams priorly $(t=3.80 ; p=0.00)$. On the other hand, the average professional anxiety scores of the prospective teachers of both groups are 157.90 and 159.33, respectively, and the difference between these two averages is not statistically significant $(\mathrm{t}=2.16: \mathrm{p}=0.03)$.

g) Independent groups t-test results related to whether prospective teachers' teaching profession perception and professional anxiety levels change according to the status of taking PPSE are given in Table 12.

Table 12.

t-test Results According to the Status of Taking PPSE

\begin{tabular}{|c|c|c|c|c|c|c|c|}
\hline Scale & Variable & $\mathbf{N}$ & Average & S.D. & $\mathbf{t}$ & sd & p \\
\hline \multirow{2}{*}{ Perception } & Yes & 325 & 78.29 & 11.23 & \multirow{2}{*}{2.86} & \multirow{2}{*}{385} & \multirow{2}{*}{$0.01 *$} \\
\hline & No & 62 & 73.81 & 11.90 & & & \\
\hline \multirow{2}{*}{ Anxiety } & Yes & 325 & 158.42 & 39.74 & \multirow{2}{*}{-0.20} & \multirow{2}{*}{385} & \multirow{2}{*}{0.85} \\
\hline & No & 62 & 159.48 & 37.96 & & & \\
\hline
\end{tabular}

$* p<0.05$

When Table 12 is examined, it is seen that teaching profession perception scale mean scores of the prospective teachers of whom will and will not take PPSE are 78.29 and 73.81, respectively, and the difference between the two means is statistically significant in favor of prospective teachers who will take PPSE $(\mathrm{t}=2.86 ; \mathrm{p}=0.01)$. On the other hand, it is seen that the average of the professional anxiety scale scores of the prospective teachers who will and will not take PPSE are 158.42 and 159.48, respectively, and the difference between these two averages is not significant $(\mathrm{t}=-0.20 ; \mathrm{p}=0.85)$.

\section{DISCUSSION, CONCLUSION and SUGGESTIONS}

1- In the present study, the finding that the teaching profession perceptions of prospective teachers are at medium level is an indicator that the perception of prospective teachers of teaching skills, career choice and glorifying teaching profession is at moderate level. When the literature on prospective teachers' teaching profession perceptions is reviewed, the data of the study by Çermik et al. (2010) concerning that 15 of the 71 female prospective teachers and 48 of the 86 male prospective teachers would not choose the profession again support the current research data. The findings considering that the reasons of preference of the profession are mainly due to their own desire and job security (Erdemir, 2010); the fact that they like teaching profession and think that teaching profession is prestigious (Erus \& Zeren, 2017) and regard teaching profession as respectable (Gülşen \& Gündüz, 2016) also promote the findings of the present research. The data indicating that prospective teachers prefer teaching profession mostly for moral reasons and then for financial reasons, $49.7 \%$ of them perceive teaching profession as educators and guides (Kart, 2016); they believe that a great deal of responsibility and sacrifice is needed in the realization of the teaching profession (Özdemir \& Erol, 2015) are also parallel with the data of the present research. The studies stating that professional teachers' reasons of preferring teaching profession are individual and systemic factors such as interest in the profession, sufficiency of the score obtained in the university entrance exam, suitability to the personalities of the field, and the possibility of finding a job (Owen-Korkut et al., 2012); 55.62\% of them chose the teaching profession because they love it and $48.75 \%$ of them want to change their fields when they have an opportunity (Taş, 2010); most of them have chosen this profession because of their interest and affection and they find teaching profession suitable for them (Tataroğlu et al., 2011); the factors that are effective in choosing this profession are that it is appropriate to their personality and it is their ideal profession (Y1lmaz \& Doğan, 2015) also support the data of the present research. 
2- It has been determined that, in teaching profession perception scale, the mean scores of male and female prospective teachers are at moderate level and the difference between the two averages is statistically significant in favor of females $(\mathrm{t}=4.01 ; \mathrm{p}=0.00)$; the average scores of the prospective teachers who stated the reason for participating in pedagogical formation certificate program as to do the teaching profession or just to get the certificate are moderate and the difference between the two averages is statistically significant in favor of the ones whose reason is to do the teaching profession $(\mathrm{t}=8,02 ; \mathrm{p}=$ $0,00)$; the perception scale mean scores of prospective teachers who preferred and who did not prefer a teaching department in the university entrance exam priorly are at moderate level and the difference between the two averages is statistically significant in favor of the ones who preferred a teaching department in the university entrance exam priorly; the perception scale mean scores of the prospective teachers who will and will not take PPSE are at moderate level and the difference between the two averages is statistically significant in favor of the ones willing to take PPSE; the average perception scale scores of undergraduate and graduate prospective teachers, currently employed and unemployed prospective teachers, prospective teachers between the ages of 20-30 and above 31 are at moderate level and there is no significant difference between the mean scores of these two groups. According to the data obtained, it has been found that the teaching profession perception of the female prospective teachers towards the teaching profession is higher. This is an indication that the perception of teaching skills, career choice and glorification of teaching is more intense among female prospective teachers. In the studies conducted by Eskicumalı et al. (2001) and Saban (2003), it has been concluded that in most of the research in Turkey the participants perceive teaching profession as a "female profession", and thus, these studies can explain that female prospective teachers have higher perceptions towards the profession within the scope of this research. The higher perception level of the prospective teachers to do the teaching profession may be an indication that they think they have made a more correct decision in their vocational preferences, acquire teaching skills through this program and perceive the teaching profession as a valuable profession than others. In the study conducted by Erdemir (2010), it has been determined that the prospective teachers prefer the program voluntarily is the most important reason, and Erus and Zeren (2017) have found that the most common reason for prospective teachers to participate in a pedagogical formation education program was that they liked the teaching profession. These findings coincide with the finding of the present research which prospective teachers taking this program to do the teaching profession have higher perceptions towards the teaching profession. Gülşen and Gündüz (2016) have found that most of the prospective teachers regard teaching profession as respectable and all of them want to perform this profession; these findings are also parallel with the finding of the present study that prospective teachers taking this program to do the teaching profession have higher perceptions about the teaching profession. In the present study, it has been found that prospective teachers who preferred a teaching department in university entrance exam priorly have higher professional perceptions than the ones who did not; this finding is an indication that the prospective teachers, having adopted teaching profession, have the basic qualifications required by the profession and already have perceptions about teaching skills, professional choice, and glorification of teaching (Acat et al., 2005). Within the scope of this research, teaching profession perceptions of the prospective teachers who will take PPSE have higher perceptions than those who will not; in other words, these prospective teachers are aware of the fact that they have to take PPSE in order to work as a teacher at a state institution and they can be appointed according to the results of this examination. In the study conducted by Erdemir (2010), it was found that job security was among the reasons for prospective teachers to choose this profession with a rate of $22.6 \%$. In the present study, it is also supported that teaching profession perceptions of the prospective teachers who will take PPSE are more meaningful. It is found that the average teaching profession perception scale scores of the prospective teachers being undergraduate students and graduate, currently employed and unemployed, between the ages of 20-30 and above 31 are at moderate level and there is no significant difference between the average scores of these two groups. This finding may be due to the fact that prospective teachers' teaching profession perceptions for all age groups are at similar and medium level, that they are still in the pupillage, and they do not have any experience about teaching yet; as Can (1987, p. 160) states, individuals form their own professional ideas and perceptions within the experiences they gain during both their pupillage and professional life. Karadag (2012) found that first grade undergraduate students have higher positive attitudes and perceptions towards teaching profession; however, his/her finding does not match the findings of the present study that the teaching profession perception scale's mean scores of the undergraduate students and graduate prospective teachers, of the 20-30-year and above 31-year age groups are moderate and there is no significant difference between the mean scores of these two groups.

3- According to the data obtained from the research, it is determined that the prospective teachers' professional anxiety is at moderate level. This finding of the present study is supported by some of the studies in the literature (Bozdam \& Taşğın, 2011; Keskin, 2017; Serin et al., 2015; Tabancalı et al., 2016). 
In the study conducted by Karamustafaoğlu and Özmen (2004), the findings, that most of the prospective teachers in the scope of their research could not meet their expectations of the profession, they think that their profession is not respected, and they are worried about the future, support the findings of the present study. In the study conducted by Özdemir and Erol (2015), prospective teachers who receive pedagogical formation education emphasize the difficulties experienced in performing the teaching profession and the required responsibilities and sacrifice. Difficulties, responsibilities, and sacrifice being experienced by teachers in performing their teaching profession cause them to experience professional anxiety; therefore, this finding supports the finding of the present study that the prospective teachers have moderate professional anxiety as well. The professional anxiety scale scores of male and female prospective teachers are 154.69 and 168.04, respectively, and the difference between these two averages is statistically significant in favor of male prospective teachers. The finding of present study that the professional anxiety level of male prospective teachers is higher than that of females is supported by the findings of the studies conducted by Akgün and Özgür (2014) and Donmuş et al. (2007). The finding that male prospective teachers experience more task-centered anxiety (Gümrükçü Bilgici \& Deniz, 2016) also partially supports the finding that male prospective teachers have higher general professional anxiety than females. This finding of the present study shows that male prospective teachers are more concerned about the tasks required by the profession, financial reasons, communication with students, colleagues, school administration and parents, personal development studies and the possibility of being appointed as a teacher. It is also determined that the average of the professional anxiety scale scores of currently employed and unemployed prospective teachers in the study is at moderate level and the difference between these two averages is statistically significant in favor of the currently employed prospective teachers. This finding of the present study is not in line with the findings of Doğan and Çoban (2009) stating that those who are pessimistic about finding a job have higher professional anxiety levels. The reason for higher levels of occupational anxiety among the prospective teachers who are currently employed in the study may be because these prospective teachers will have to change their current professions if they are appointed as teachers or start working in the private sector. In the study, it was seen that the anxiety scale mean scores of prospective teachers between the ages of 20-30 and above 31 are at moderate level and there is no significant difference between the mean scores of these two groups. This finding of the present study is supported by Atmaca (2013) stating that age factor does not significantly affect professional anxiety levels; however, it is not supported by Bozdam and Taşğın (2011) stating that anxiety levels decrease as age increases; it is partially supported by Dursun and Karagün (2012) finding that younger professional teachers have higher self-centered anxiety scores, yet this difference is not detected in task and student-centered anxiety types. These findings may indicate that all prospective teachers, regardless of age, are experiencing professional anxiety about teaching profession they intend to perform in the future. The finding that all prospective teachers in the current study have moderate level professional anxiety is an indication that the pedagogical formation certificate program they are receiving could not sufficiently reduce their anxiety. This is partly supported by the finding conducted by Yalçın İncik and Akay (2015) stating that only $5.6 \%$ of the prospective teachers think that the program will meet their professional competencies. The finding that the average professional anxiety scale scores of the undergraduate and graduate prospective teachers in the present study is at moderate level and there is no significant difference between the mean scores of the two groups is supported by the finding of Atmaca (2013) that the age factor of the prospective teachers does not affect their professional anxiety levels significantly. It is seen that the average professional anxiety scale scores of the prospective teachers who will and will not take PPSE are at moderate level and there is no significant difference between the mean scores of the two groups. The fact that both groups have a moderate level of professional anxiety is supported by the findings of the study by Sezgin Nartgün and Gökçer (2014). The finding that the average professional anxiety scale scores of the prospective teachers who preferred a teaching department in the university entrance exam are at moderate level and there is no significant difference between the average scores of these two groups may be because these prospective teachers have not yet started their profession and thus their perceptions about the teaching profession are still moderate. Similarly, according to the findings of the study conducted by Abalı Öztürk et al. (2019), prospective teachers who have preferred a teaching department in different rankings in the placement of the undergraduate program have similar professional anxiety levels and there is no significant difference between them. The prospective teachers who stated the reason for participating in pedagogical formation program as not only to do the teaching profession but also just to get the certificate have moderate professional anxiety scale scores, and there is no significant difference between the mean scores of these two groups. This finding is an interesting indicator of the fact that prospective teachers who participate in this program just to get a certificate are experiencing professional anxiety like those aspiring to do teaching profession. 
4- According to the data obtained from the study, it is determined that there is a low, positive, and significant relationship between the prospective teachers' perception of teaching profession and professional anxiety levels $(\mathrm{r}=0.15 ; \mathrm{p}<0.01)$. This finding of the present study is supported by findings of some of the studies in the literature stating that prospective teachers perceive teaching profession as life, guidance, devotion, quality and management, as well as "disappointment" as they experience a little bit professional anxiety (Çocuk et al., 2015); do not perceive their profession as respected, majority of them are unable to meet their expectations regarding their profession, and have professional anxiety about the future (Karamustafaoğlu \& Özmen, 2004); will need a pedagogical formation education certificate in the future despite the respectful perception of the teaching profession and are worried about the future (Erus \& Zeren, 2017). These findings are important indicators that they are experiencing financial, task and personal anxiety despite their positive perceptions towards the teaching profession.

Although presenting important results, the present study has been a quantitative one. Empirical studies can be carried out which make it possible to make more in-depth and causal inferences about qualitative and more in-depth perception and anxiety levels of prospective teachers. The data obtained in the present study are cross-sectional data reflecting the opinions of prospective teachers over a certain period. Longitudinal future studies can be carried out with prospective teachers especially after being appointed as teachers. Experimental studies can also be conducted to prospective teachers who have medium level of anxiety and teaching profession perception to decrease their professional anxiety levels and increase their level of professional perceptions. 


\section{REFERENCES}

Abalı Öztürk, Y., Şahin, Ç., Demir, M. K., \& Arcagök, S. (2019). Examining the anxiety levels of teacher candidates who continue their education in the department of basic education towards the teaching profession. Journal of Social Sciences, Eskişehir Osmangazi University, 20(Special issue), 107-122. https://doi.org/10.17494/ogusbd.548291

Acat, B., Balbă̆, M. Z., Demir, B., \& Görgülü, A. (2005). The perceptions of the teaching profession of students who are studying at the faculty of science and literature, faculty of education, and master's without thesis. Buca Faculty of Education Journal, 17, 27-35.

Akgün, F., \& Özgür, H. (2014). Examination of the anxiety levels and attitudes of the information technology of pre-service teachers' towards the teaching profession. Journal of Theory and Practice in Education, 10(5), 1206-1223.

Akyüz, Y. (1978). Effects of teachers on social change in Turkey. Doğan.

Atmaca, H. (2013). Professional concerns of prospective teachers studying at German, French and English language teaching departments. Turkish Studies, 8(10), 67-76.

Balc1, A. (2005). Research in social sciences: Method, techniques, and principles. TDFO.

Boz, Y. (2008). Turkish student teachers' concerns about teaching. European Journal of Teacher Education, 31(4), 367-377.

Bozdam, A., \& Taşğın, Ö. (2011). Examining the professional anxiety levels of prospective teachers in terms of some variables. Selçuk University Journal of Physical Education and Sport Science, 13(1), 44-53.

Büyüköztürk, Ş. (2011). Manual of data analysis for social sciences. Pegem.

Cabı, E., \& Yalçınalp S. (2009, May 6-9). The opinions of the teacher candidates about the anxiety levels of using vocational and educational technologies. IV. International Educational Technology Conference (IETC), Hacettepe University, Ankara.

Cabı, E., \& Yalcinalp, S. (2013). Occupational Anxiety Scale (OAS) for prospective teachers: Validity and reliability study. Hacettepe University Journal of Education, 44, 85-96.

Can, Ş. (2010). Attitudes of non-thesis graduate students towards the teaching profession. Journal of Social Sciences and Humanities Researches, 24, 13-28.

Chong, S., \& Low, E.-L. (2009). Why I want to teach and how I feel about teaching formation of teacher identity from pre-service to the beginning teacher phase. Educational Research for Policy Practice, 8, 59-72. https://doi.10.1007/s10671-008-9056-z

Chotas, T. J., \& Thoresen, C. E. (1976). Teacher anxiety: A review with recommendations. Rewiew of Educational Research, 46(2), 159-184.

Cronbach, L. J., Schonemann, P., \& McKie, D. (1965). Alpha coefficients for stratified- paralel tests. Educational and Psychological Measurement, 25, 291-312.

Çakmak, M. (2008). Concerns about teaching process: Student teachers' perspective. Educational Research Quarterly, 31(3), 57-77.

Çakmak, Ö., \& Hevedanlı M. (2005). Examining the anxiety levels of the students of Biology departments of education and science-literature faculties in terms of various variables. Electronic Journal of Social Sciences, 4(14), 115-127.

Çermik, H., Doğan, B., \& Şahin, A. (2010). Pre-service primary school teachers' reasons for choosing teaching profession. Pamukkale University Journal of Education, 28(2), 201-212.

Çocuk, H. E., Yokuş, G., \& Tanrıseven, I. (2015). Self-efficacy and metaphorical perceptions of pedagogical formation students regarding teaching: Mersin University example. Mustafa Kemal University Journal of Social Sciences Institute, 12(32), 373-387.

Çokluk, Ö., Şekercioğlu, G., \& Büyüköztürk, Ş. (2010). Multivariate statistics for social sciences: SPSS and LISREL applications. Pegem.

Çubukçu, Z., \& Dönmez, A. (2011). Examining the professional anxiety levels of teacher candidates. Journal of Theory and Practice in Education, 7(1), 3-25.

Dilmaç, O. (2010). Examining the anxiety levels of visual arts teacher candidates in terms of various variables. The Journal of Fine Arts Institute of Ataturk University, 24, 49-65.

Dinçer, B., Yılmaz, S., \& Keşan, C. (2015). The investigation of professional perception and hopelessness levels of computer and instructional technologies pre-service teacher. Journal of Educational Sciences Research, 5(1), 191-204.

Donmuş, V., Akpınar, B., \& Eroğlu, M. (2017). Examining the relationship between teacher candidates' academic self-efficacy and professional concerns. Mustafa Kemal University Journal of Social Sciences Institute, 14(37), 1-13.

Doğan, T., \& Çoban, A. E. (2009). Examining the relationship between faculty of education students' attitudes towards the teaching profession and their anxiety levels. Education and Science Journal, 34(153), 157168. 
Dursun, S., \& Karagün, E. (2012). Investigation of professional anxiety levels of teacher candidates: A study on senior students of Kocaeli University School of Physical Education and Sports. Kocaeli University Journal of Social Sciences, 24, 93-112.

Erdem, A. R., Gezer, K., \& Çokadar, H. (2005, September 28-30). Non-thesis graduate students' attitudes towards the teaching profession at the department of secondary education science-mathematics and social fields teaching. XIV. National Congress on Educational Sciences, Denizli, Turkey.

Erdemir, N. (2010). Physics teacher candidates' reasons for choosing the department and its effect on academic success in mechanics. Erzincan University Journal of Education Faculty, 1(1), 1-14.

Erus, S. M., \& Zeren, Ş. G. (2017). Pre-service teachers' career adaptation towards the teaching profession. Journal of Higher Education and Science, 7(3), 657-668. https://doi.10.5961/jhes.2017.242

Fuller, F. F. (1969). Concerns of teachers: A developmental conceptualization. American Educational Research Journal, 6, 207-226. http://www.jstor.org/stable/1161894.

Fuller, F. F., Parsons, J. S., \& Watkins, J. (1974). Concerns of teachers: Research and reconceptualization. Annual Meeting of the American Education Association, Chicago, IL. http://eric.ed.gov/?id=ED091439

Gay, L. R., \& Airasian, P. (2000). Educational research: Competencies for analysis and application (6th ed.). Prentice-Hall, Inc.

Ghaith, G., \& Shaaban, K. (1999). The relationship between perceptions of teaching concerns, teacher efficacy, and selected teacher characteristics. Teaching and Teacher Education, 15, 487-496.

Gözler, A., Bozgeyikli H., \& Avc1, A. (2017). Examining the success orientation and professional anxiety levels of prospective classroom teachers. Bolu Abant Izzet Baysal University Journal of Faculty of Education, 17(1), 189-211.

Gülşen, C., \& Çetin Gündüz, H. (2016). The opinions of the teacher candidates who received pedagogical formation education about the teaching profession and teaching practice. International Journal of Social Sciences and Education Research, 2(3), 870-883.

Gümrükçü Bilgici, B., \& Deniz, Ü. (2016). Examination of pre-school teacher candidates' occupational anxieties according to some demographic characteristics. Cumhuriyet International Journal of Education-CIJE, 5(1), 53-70.

Kafkas, M. E., Açak, M., Çoban, M., \& Karademir, T. (2010). The relationship between pre-service physical education teachers' self-efficacy perceptions and professional anxieties. Inonu University Journal of the Faculty of Education, 11(2), 93-111.

Kalemoğlu Varol, Y., Erbaş, M. Y., \& Ünlü, H. (2014). The predictive power of the professional anxiety levels of physical education teacher candidates at their attitudes towards the teaching profession. Spormetre the Journal of Physical Education and Sport Sciences, 12(2), 113-123.

Karadağ, R. (2012). Turkish teacher candidates' attitudes towards the teaching profession and the reasons for their preference for the teaching profession. e-Journal of New World Sciences Academy, 7(2), 4C0133.

Karamustafaoğlu, O., \& Özmen, H. (2004). A research on the value attached to the teaching profession in our society and among teacher candidates. Journal of Values Education, 2(6), 35-49.

Karasar, N. (2013). Scientific research method (25th ed.). Nobel.

Kart, M. (2016). Metaphoric perceptions of pedagogical formation students and education faculty students about the concept of 'teacher' [Unpublished master's thesis]. Pamukkale University.

Karademir, E., \& Tezel, Ö. (2011). Examining prospective teachers' attitudes and concerns towards the teaching profession. e-Journal of New World Sciences Academy, 6(3), 2005-2018.

Kaya, A., \& Büyükkasap, E. (2005). Physics teaching department students' profiles, attitudes and concerns towards the teaching profession: Erzurum example. Kastamonu Education Journal, 13(2), 367-380.

Keskin, Y. (2017). The attitude and anxiety levels of geography teacher candidates towards the teaching profession (Erzurum Example). e-Kafkas Journal of Educational Research, 4(2), 43-57.

Kiraz, Z., \& Dursun, F. (2015). Perceptions of teacher candidates receiving pedagogical formation education about the education they have received. Mersin University Journal of the Faculty of Education, 11(3), 10081028. https://doi.10.17860/efd.37544

Kirk, R. (2008). Statistics: An introduction. (5th ed.). Thomson-Wadsworth.

Köse, H. S. (2006). Professional concerns of prospective music teachers. Mehmet Akif Ersoy University Journal of Education Faculty, 7(12), 80-89.

Kuzgun, Y. (2000). Vocational counselling theories applications. Nobel.

Luthans, F. (1995). Organizational behavior. McGraw-Hill.

Marso, R. N., \& Pigge, F. L. (1998, October 14-17). A seven year multivariate longitudinal study of the changes in anxiety about teaching through preparation and early years of teaching. Annual Conference of the Midwestern Educational Research Association. Chicago, IL.

Memişoğlu, S. P. (2006). What kind of teacher? In Proceedings Book of the Symposium on Reconstruction in Secondary Education (pp. 334-338). Ministry of National Education, Turkey. 
Nayır, K. F., \& Taneri, P. O. (2010). Examining the opinions of Karatekin University pedagogical formation students regarding the reasons for choosing teaching profession according to gender variable. Cankiri Karatekin University Journal of Faculty of Letters (KAREFAD), 2(1), 1-12.

Nenty, H. J., Moyo, S., \& Phuti, F. (2015). Perception of teaching as a profession and UB teacher trainees' attitude towards training programme and teaching. Educational Research and Reviews, 10(21), 2797-2805. https://doi.10.5897/ERR2015.2441

Owen-Korkut, F., Kepir, D. D., Özdemir, S., Ulaş, Ö., \& Yılmaz, O. (2012). University students' reasons to choose a department. Mersin University Journal of the Faculty of Education, 8(3),135-151.

Özday1, N. (2000). Evaluation of the occupational concerns of students studying at the faculty of education in terms of total quality management. Marmara University Atatürk Education Faculty Journal of Educational Sciences, 12, 233-248.

Özdemir, A. (2008). Advanced research methods and applications in management science. Beta.

Özdemir, T. Y., \& Erol, Y. C. (2015). Perceptions of teacher candidates taking pedagogical formation education about the concepts of school, teaching and student. Manisa Celal Bayar University Journal of Social Science, 13(4), 215-244. https://doi.org/10.18026/cbusos.48652

Özoğlu, M. (2011, December 11). Turkey's “teacher training” policy. Education and Science Policies of Turkey in the 21st Century Symposium, Ankara, Turkey.

Öztürk, B., Okyay Doğan, O., \& Erdamar Koç, G. (2005). Comparison of the perceptions of the education faculty student and the graduates of the faculty of science and literature towards the teaching profession (Gazi University sample). The Journal of Turkish Educational Sciences, 3(1), 1-22.

Özyürek, R., \& Kılıç Atıcı, M. (2007). Determining the resources that help university students in their career choice decisions. The Turkish Psychological Counseling and Guidance Journal, 2(17), 33-42.

Pigge, F. L., \& Marso, R. N. (1987). Relationships between student characteristics and changes in attitudes, concerns, anxieties, and confidence about teaching during teacher preparation. The Journal of Educational Research, 81(2), 109-115.

Pigge, F. L., \& Marso, R. N. (1990). A longitudinal assessment of the affective impact of pre- service training on prospective teachers. The Journal of Experimental Education, 58(4), 283-289.

Pituch, K. A., \& Stevens, J. P. (2016). Applied multivariate statistics for the social sciences: Analysis with SAS and IBM's SPSS (6th ed.). Taylor and Francis.

Reeves, C. K., \& Kazelskis, R. (1985). Concerns of preservice and inservice teachers. Journal of Educational Research, 78(5), 267-271.

Robitzsch, A. (2017). Package 'sirt'. http://r.meteo.uni.wroc.pl/web/packages/sirt/sirt.pdf

Semerci, N. (2001 Haziran 7-9). The attitudes of three different groups towards teaching. X. National Congress on Educational Sciences, Bolu, Turkey.

Serin, M. K., Güneş, A. M., \& Değirmenci, H. (2015). The relationship between the attitudes of primary school teachers' attitudes towards the teaching profession and their level of anxiety towards the profession. Cumhuriyet International Journal of Education-CIJE, 4(1), 21-34.

Sezgin Nartgün, Ş., \& Gökçer, İ. (2014). The metaphorical perceptions of teacher candidates who receive pedagogical formation education about their profession, future, employment and education policies. $e$ International Journal of Educational Research, 5(4), 57-69.

Şahin, İ. (2011). Teacher candidates' views on teacher employment and professional future. Educational Sciences: Theory and Practice, 11(3), 1167-1184.

Tabancalı, E., Çelik, K., \& Korumaz, M. (2016). The level of pre-service teacher professional concerns in the context of Turkey. e-International Journal of Educational Research, 7(3), 63-73. https://doi.10.19160/e-ijer.89817

Tarman, B. (2012). Prospective teachers' beliefs and perceptions about teaching as a profession. Educational Sciences: Theory \& Practice, 12(3), 1964-1973.

Taş, M. Y. (2010). Profile of social studies teacher candidates of Demirci Education Faculty and evaluation of their reasons for preferring social studies teaching. Manisa Celal Bayar University Journal of Social Science, 10(2), 64-76.

Taşğın, Ö. (2006). Examination of occupational anxiety levels of teacher candidates studying at physical education and sports college in terms of some variables. Kastamonu Education Journal, 14(2), 679-686.

Tataroğlu, B., Özgen, K., \& Alkan, H. (2011, April 27-29). Pre-service mathematics teachers' reasons for preference and expectations as teaching. 2nd International Conference on New Trends in Education and Their Implications, Antalya-Turkey.

Terzi, A. R., \& Tezci, E. (2007). Necatibey Faculty of Education students' attitudes towards the teaching profession. Educational Administration: Theory and Practice, 52, 593-614.

Tümerdem R. (2007). Factors affecting anxiety of senior year chemistry students of Dicle University faculty of education and faculty of science and literature. Electronic Journal of Social Sciences, 6(20), 32-45. 
Türkdoğan, S. C. (2014). Occupational anxieties according to the factors that affect pre-service teachers' choosing the teaching profession [Unpublished master's thesis]. Pamukkale University.

Uluğ, M., Özden, M. S., \& Ery1lmaz, A. (2011). The effects of teachers' attidutes on students personality and performance. Prodecia-Social and Behavioral Sciences, 30, 738-742.

Ünaldı, Ü., \& Alaz, A. (2008). Examining the professional anxiety levels of prospective geography teachers in terms of some variables. Ahmet Keleşoğlu Faculty of Education Journal, 26, 1-13.

Üredi, L., \& Üredi, I. (2007, April 27-29). Classroom teachers' perceptions of the teaching profession as a predictor of their preferred teaching styles. 6th International Primary Teacher Education Symposium, Eskişehir, Turkey.

Yalçın İncik, E., \& Akay, C. (2015). The opinions of the teacher candidates studying at the education faculty and pedagogical formation certificate programs about the proficiency of teaching profession. Ahi Evran University Journal of Kırşehir Education Faculty (JKEF), 16(2), 179-197.

Yazic1, H. (2009). Teaching profession, sources of motivation and basic attitudes: A theoretical view. Kastamonu Education Journal, 17(1) 33-46.

Yılmaz, N., \& Doğan, N. (2015). Factors affecting the profession preferences of pre-service Mathematics teachers: Hacettepe University example. Bolu Abant Izzet Baysal University Journal of Faculty of Education, 15(1), 405-421.

Yilmaz, F., Göçen, S., \& Yılmaz, F. (2013). Perceptions of pre-service teachers on the concept of teacher: A metaphorical study. Mersin University Journal of The Faculty of Education, 9(1), 151-164. 


\section{GENIŞLETILMIŞ ÖZET}

\section{Gİiș}

Öğretmenlerin başarıları üzerinde en az mesleki yeterlikleri kadar etkili olan diğer özellikler kişisel ve psikolojik özelliklerdir (Demirel, 2003; Yazıcı, 2009). Bu bağlamda, öğretmen adaylarının bu mesleğe yönelik algı ve mesleki kaygılarının mesleki başarıyı etkileyen önemli psikolojik değişkenler olduğu söylenebilir. Bir öğretmenin iş hayatında yeni öğretim yöntem ve teknikleri kullanabilmesi, öğretim stratejilerini etkili bir şekilde geliştirebilmesi, öğrenci gelişimini takip edebilmesi ve etkili iletişim becerilerine sahip olması mesleki formasyonuna ilişkin algı düzeyinin yüksek olmasına bağlıdır (Üredi \& Üredi, 2007). Fuller (1969, s. 211) öğretmen adaylarının mesleğe ilişkin kaygılarını öğrenci, görev ve ben merkezli kaygılar olmak üzere üç grup altında toplamıştır. Öğretmen adaylarının gelecekteki mesleki performanslarının sahip oldukları kişisel ve psikolojik özelliklerinden etkileneceği ve süresi ve niteliğiyle tartışmalara neden olan pedagojik formasyon sertifika programlarının çeșitli boyutlarının incelenmesinin bu tartışmalara daha pedagojik bir bakış açısı kazandırabileceği düşünüldüğünden dolayı bu eğitime dahil olan adayların öğretmenlik mesleğini algılama biçimlerinin ve mesleki kaygı düzeylerinin değerlendirilmesinin önemli olduğu düşünülmektedir.

\section{YÖNTEM}

Mevcut araştırma, iki ve daha fazla değişken arasındaki birlikte değişimi belirlemeyi amaçlayan ilişkisel tarama modeli ve var olan durumu analiz etmeye yarayan betimsel tarama modelinde yürütülmüştür (Karasar, 1995). Araştırma, Türkiye'de Batı Karadeniz Bölgesi'nde bulunan bir üniversitenin Eğitim Fakültesinde pedagojik formasyon eğitimi sertifika programındaki gönüllü 387 öğretmen adayı ile yürütülmüş ve veri analizinde ortalama, standart sapma, Pearson korelasyon katsayısı, $t$ testi ve Levene testi kullanılmıştır.

Araştırmada, araştırmacı tarafindan hazırlanmış Kişisel Bilgi Formu; Cabı ve Yalçınalp (2013) tarafindan geliştirilmiş olan Öğretmen Adaylarına Yönelik Mesleki Kaygı Ölçeği ve Öztürk vd. (2005) tarafindan geliştirilmiş olan Öğretmenlik Mesleğine Yönelik Algı Ölçeği kullanılmıştır. Mevcut araştırmada, Öğretmen Adaylarına Yönelik Mesleki Kaygı Ölçeği’nin tümünün Cronbach alpha iç tutarlık katsayısı 0,853; Öğretmenlik Mesleğine Yönelik Algı Ölçeği’nin tümünün Cronbach alpha iç tutarlık katsayısı 0,78 bulunmuştur.

\section{BULGULAR, TARTIŞMA ve ÖNERILER}

Araştırmanın, öğretmen adaylarının mesleğe yönelik algılarının orta düzeyde olduğu bulgusu bireylerin öğretim becerisine, meslek tercihine ve öğretmenliği yüceltmeye yönelik algı düzeylerinin orta seviyede olduğunun bir göstergesidir ve Çermik vd. (2010), Erdemir (2010), Erus ve Zeren (2017), Kart (2016), Taş (2010) ve Yılmaz ve Doğan (2015) tarafindan yapılmış çalışmalarla ve Bozdam ve Taşğın (2011), Keskin (2017), Serin vd. (2015), Tabancalı vd. (2016) ve Karamustafaoğlu ve Özmen (2004) tarafindan yapılan çalışmaların bulgularıyla örtüşmektedir. Araştırma kapsamındaki öğretmen adaylarının büyük bir çoğunluğunun mesleğe ilişkin beklentilerine karşılık bulamamaları, mesleklerinin saygın görülmediğini düşünmeleri ve gelecek kaygısı taşımaları; Özdemir ve Erol (2015) tarafindan yapılan çalışmada öğretmenlik mesleğinin yerine getirilmesinde yaşanılan zorluklar, gerektirdiği sorumluluk ve fedakârlıklar mevcut çalışmanın öğretmen adaylarının orta düzeyde mesleki kaygiya sahip olduğu bulgusunu da destekler niteliktedir.

Araştırmada, algı ölçeğindeki ortalama puanların, kadın, öğretmenlik yapmak amacıyla katılan, üniversite giriş sınavlarında öğretmenlik bölümünü tercih etmiş olan ve KPSS'ye girecek olan öğretmen adayları lehine anlamlı olduğu; 20-30 yaş ve 31 ve üstü yaş aralığındaki, lisans öğrencisi ve lisans mezunu ve çalışan ve çalışmayan öğretmen adaylarının ortalama algı ölçeğinde ortalama puanlar arasında anlamlı fark olmadığı belirlenmiştir. Eskicumalı vd. (2001) ve Saban (2003) tarafından yapılan çalışmalarda Türkiye'deki araştırmalarda öğretmenlik mesleğinin adaylar tarafından "kadın" mesleği olarak görülmesinin araştırma kapsamındaki kadın adayların mesleğe yönelik algılarının daha yüksek olmasında etkili olduğu söylenebilir. Mevcut araştırmanın sertifika programına öğretmen olmak için katılan adayların mesleki algılarının daha yüksek olduğu bulgusu Erdemir (2010), Erus ve Zeren (2017) ve Gülşen ve Gündüz (2016) tarafindan yapılan çalışma bulgularıyla desteklenmektedir. Mevcut araştırmada, üniversite giriş sınavlarında öğretmenlik bölümü tercih etmiş olan öğretmen adaylarının daha yüksek mesleki algıya sahip olduğu bulgusu ise öğretmenliği benimsemiş olan bu öğretmen adaylarının mesleğin gerektirdiği ve Acat vd.ne göre (2005, s. 29) mesleki algıyla doğrudan ilgili olan temel niteliklere sahip olduğunun ve bu adayların öğretim becerisine, meslek tercihine ve öğretmenliği yüceltmeye yönelik algılarının halihazırda var olduğunun bir göstergesidir. KPSS'ye girecek öğretmen adaylarının öğretmenlik mesleğine yönelik algılarının daha yüksek olması ise bu adayların devlet kurumunda öğretmenlik yapabilmek için KPSS'ye girmeleri gerektiğinin ve bu sınav sonucuna göre atanabileceklerinin bilincinde olduklarının bir göstergesidir ve Erdemir (2010) tarafından yapılan çalışmanın bulgusu desteklenmektedir. 20-30 yaş ve 31 ve üstü yaş aralığındaki, lisans öğrencisi ve lisans mezunu ve çalışan ve çalışmayan öğretmen adaylarının ortalama algı ölçeği puanlarının orta 
düzeyde olduğu ve iki grubun ortalama puanları arasında anlamlı fark olmadığı bulgusu ise araştırma kapsamında bütün yaş aralığındaki öğretmen adaylarının öğretmenliğe yönelik algılarının benzer ve orta düzeyde olması, onların henüz öğrencilik döneminde olmalarından ve öğretmenlikle ilgili herhangi bir deneyime sahip olmamalarından kaynaklanıyor olabilir.

Kaygı ölçeğindeki ortalama puanların, erkek ve çalışan öğretmen adaylarının lehine anlamlı olduğu; 20-30 yaş ve 31 ve üstü yaş aralığındaki, lisans öğrencisi ve lisans mezunu, pedagojik formasyon eğitimine katılma nedenini öğretmenlik yapmak veya sadece sertifika almak olarak belirten, üniversite giriş sınavlarında öğretmenlik bölümünü tercih etmiş olan ve olmayan ve Kamu Personeli Seçme Sinavi'na (KPSS) girecek ve girmeyecek öğretmen adaylarının ortalama puanları arasında anlamlı fark olmadığ1 görülmüştür. Araştırma kapsamındaki erkek adayların mesleki kaygılarının kadın adaylardan daha yüksek olduğu bulgusu literatürde Akgün ve Özgür (2014), Donmuş vd. (2007) ve Gümrükçü Bilgici ve Deniz (2016) tarafından yapılmış araştırma bulgularıyla desteklemektedir. Araştırma kapsamındaki çalışan ve çalışmayan öğretmen adaylarının kaygı ölçeği puanları ortalamasının orta düzeyde olduğu ve çalışan adayların lehine istatistiksel olarak anlamlı olduğu bulgusu bu adayların öğretmen olarak çalışmaya başladıkları taktirde iş değiştirecek olmalarından kaynaklanıyor olabilir ve Atmaca (2013) ve Dursun ve Karagün (2012) tarafından yapılan çalışmalarla desteklenmektedir. Araştırma kapsamındaki 20-30 yaş ve 31 ve üstü yaş aralığındaki öğretmen adaylarının ortalama puanları arasında anlamlı fark olmadığı bulgusu, yaş fark etmeksizin tüm öğretmen adaylarının öğretmenlik mesleğine yönelik mesleki kayg1 yaşıyor olduklarının bir göstergesidir. KPSS'ye girecek ve girmeyecek öğretmen adaylarının ortalama kaygı ölçeği puanlarının orta düzeyde olduğu ve iki grubun ortalama puanları arasında anlamlı fark olmadığı bulgusu Sezgin Nartgün ve Gökçer (2014) tarafından yapılan çalışmanın bulgularıyla desteklenmektedir. Üniversite giriş sınavlarında öğretmenlik bölümünü tercih etmiş olan ve olmayan öğretmen adaylarının ortalama kaygı ölçeği puanlarının orta düzeyde olduğu ve iki grubun ortalama puanları arasında anlamlı fark olmadığı bulgusu ise bu öğretmen adaylarının henüz mesleğe başlamamış olmalarından kaynaklanıyor olabilir ve Abalı Öztürk vd. (2019) tarafından yapılan çalışmanın bulgusuyla desteklenmektedir. Pedagojik formasyon eğitimine katılma nedenini öğretmenlik yapmak veya sadece sertifika almak olarak belirten öğretmen adaylarının kaygı ölçeği puanlarının orta düzeyde olduğu ve iki grubun ortalama puanları arasında anlamlı fark olmadığı bulgusu ise ilginç bir şekilde programa sadece sertifika almak için katılmış adayların öğretmenlik yapma arzusunda olan adaylar gibi mesleki kaygı yaşıyor olduklarının göstergesidir.

Araştırmada, öğretmen adaylarının öğretmenlik mesleğine yönelik algı ve mesleki kaygı arasında düşük düzeyde, pozitif ve anlamlı bir ilişki olduğu bulgusu, öğretmen adaylarının öğretmenlik mesleğini yaşamsallık, rehberlik, özveri, nitelik ve yöneticilik olarak algılamalarının yanı sıra "hayal kırıklığı” olarak da algılamaları (Çocuk vd., 2015); mesleklerini saygın olarak algılamalarına rağmen büyük bir çoğunluğun mesleğe ilişkin beklentilerine karşılık bulamamaları ve gelecek kaygısı taşımaları (Karamustafaoğlu \& Özmen, 2004); öğretmenlik mesleğinin saygın algılamalarına rağmen ilerde pedagojik formasyon eğitimi belgesine ihtiyaç duyacak olmaları (Erus \& Zeren, 2017) bulgularıyla desteklenmektedir. Bu bulgular, öğretmen adaylarının öğretmenlik mesleğine yönelik algılarının olumlu olmasında rağmen ekonomik, görev ve kişisel kaygılar yaşıyor olduklarının önemli göstergesidir.

Öğretmen adaylarının mesleğe yönelik algı ve kaygı düzeyleri ile ilgili nitel ve daha derinlemesine ve nedensel çıkarımlarda bulunmayı mümkün kılan deneysel çalışmalar da gerçekleştirilebilir. Bu programlara katılan öğretmen adayları ile sonraki araştırmalarda boylamsal çalışmalar da yürütülebilir. Öğretmenlik mesleğine yönelik kaygı düzeyleri yüksek ve orta olan öğretmen adaylarına kaygılarını azaltmak ve mesleki algı düzeyleri düşük ve orta olan öğretmen adaylarının da algılarını arttırmak için deneysel çalışmalar yapılabilir.

\section{ARAŞTIRMANIN ETIK İZNi}

Yapılan bu çalışmada "Yükseköğretim Kurumları Bilimsel Araştırma ve Yayın Etiği Yönergesi” kapsamında uyulması belirtilen tüm kurallara uyulmuştur. Yönergenin ikinci bölümü olan "Bilimsel Araştırma ve Yayın Etiğine Aykırı Eylemler” başlığı altında belirtilen eylemlerden hiçbiri gerçekleştirilmemiştir.

\section{Etik kurul izin bilgileri}

Etik değerlendirmeyi yapan kurul adı: Bolu Abant İzzet Baysal Üniversitesi Sosyal Bilimlerde İnsan Araştırmaları Etik Kurulu

Etik değerlendirme kararının tarihi: 03.05.2019

Etik değerlendirme belgesi sayı numarası: 2019/187

\section{ARAŞTIRMACILARIN KATKI ORANI}

Araştırma tek yazarlı olduğu için yazarın katkısı \%100’dür. 


\section{ÇATIŞMA BEYANI}

Araştırmada herhangi bir kişi ya da kurum ile finansal ya da kişisel yönden bağlantı bulunmamaktadır. 